\title{
Empathy as a Moderator Variable in the Relationship between Altruistic behavior and a Social responsibility among Faculty of Nursing female students
}

"Mariam Ahmed Elshahawy

\section{Abstract:}

This study aimed to investigate the relationship between altruistic behavior and a Social responsibility, and also the relationship between empathy and altruistic behavior and a Social responsibility, and also the moderating role of empathy in the relationship between altruistic behavior and a Social responsibility. Research included (150) female students, with mean age $(21,5) \mathrm{SD}( \pm 3,4)$. Tools were: empathy scale (prepared by the researcher), altruistic behavior scale (prepared by the researcher), and Social responsibility scale (prepared by researcher). Results showed that there is a positive significant relationship between altruistic behavior and a Social responsibility, there is a positive significant relationship between empathy and altruistic behavior and a Social responsibility. Results also showed that there is a moderating role of empathy in the relationship between altruistic behavior and a Social responsibility.

Key Words: Empathy- Altruistic behavior- Social responsibility.

\section{Introduction:}

Behavior is positive when it is desirable and beneficial to others. Over the last few years, positive psychology has developed, and researchers have become increasingly interested in gaining a deep understanding of positive behavior. Attention has been focused on behaviors that affect personality including help behavior and all behaviors that facilitate living with others and enhance the positive social relations such as altruistic behavior and empathy (Zheng, Wang \& $\mathrm{Xu}, 2016:$ 1575). Empathy is a multidimensional complex construct that involves the cognitive ability to understand another person and the willingness to respond appropriately to the needs of others (LevettJones, Cant \& Lapkin, 2019: 80). This was explained by (Roberts, Strayer \& Denham, 2014: 466) as Empathy plays an important role in the development of positive behaviors at the beginning, because empathy is not just feelings, but rather a cognitive process. Empathy is a sign of positive social and ethical behavior. Contemporary research of altruism is therefore concerned with the study of the relationship 
between empathy and altruism, or the so-called empathy-altruism hypothesis (Kim \& Han, 2018: 78).

"Batson" is concerned with the relationship between empathy and altruistic behavior. This interest in empathy stems from taking the other person's views and imagining his feelings in this situation and thus giving him help. Empathy for someone who needs help raises altruistic motives to help him. "Batson" determined the factors that help to take the views of others are as follows: The person witnessed an experience similar to the experience of the other person, having relationships with the other person, guiding others to the person on how to identify the other person's point of view and feelings.

Figure (1) illustrates the hypothesis of the relationship between empathy and altruistic behavior where the motivation for altruism arises from sympathetic anxiety:

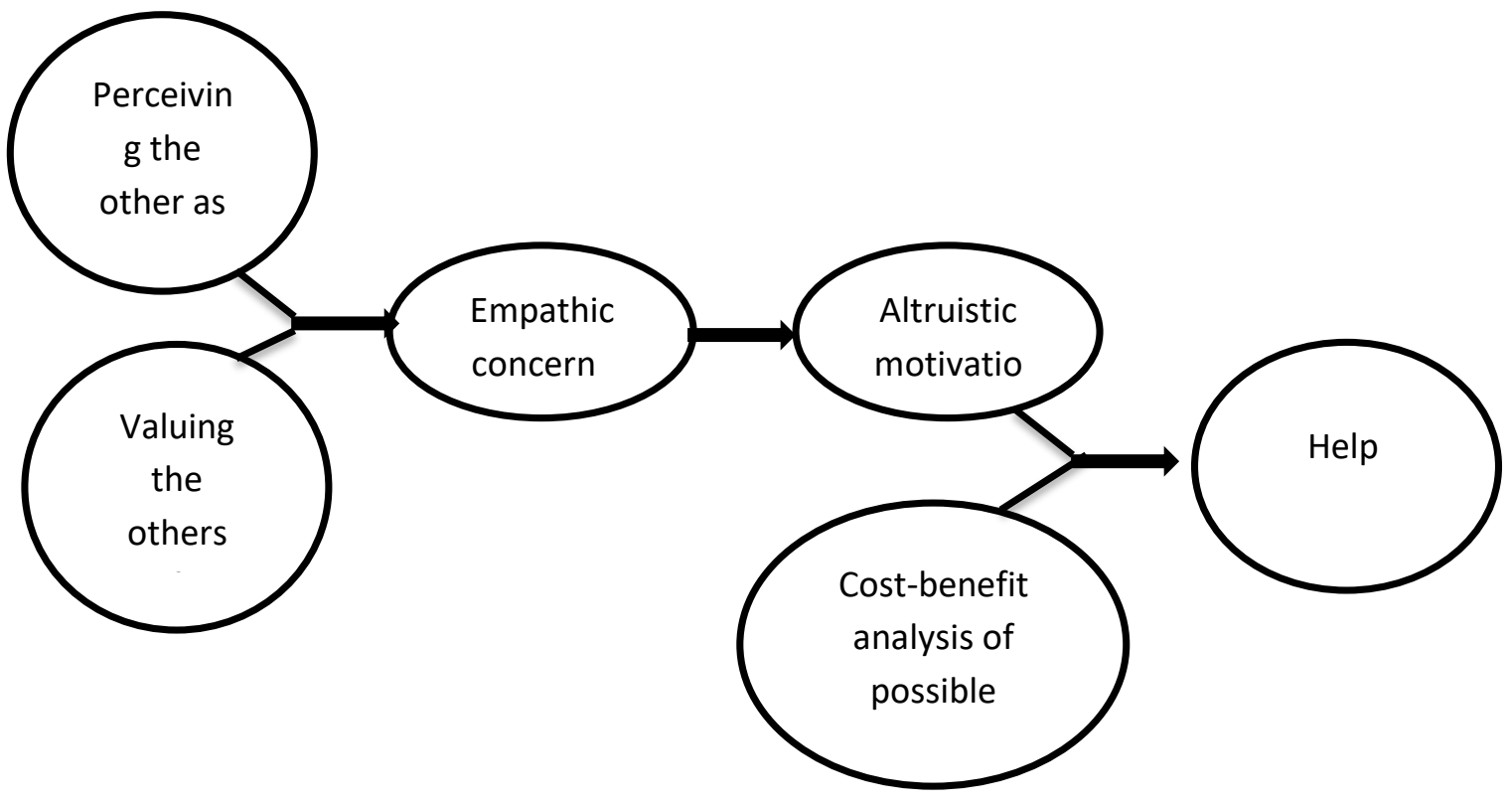

Figure (1)

\section{The hypothesis of the relationship between empathy and altruism as shown in (Batson, 2011: 80)}

"Batson" suggested that empathy leads to altruism and thus leads to positive social behavior motivated by alleviation of the negative state of the other. Researchers also view empathy as an emotional response stemming from an understanding of the emotional state of the other that is similar to what the other feels. Ethical behavior is also a high-level social behavior and the highest social behavior, involving assistance, participation and cooperation for the benefit of others (Jiang, Chen \& Wang, 2017: 493). 
Altruistic behavior involves feeling and helping others without waiting for reward, out of social responsibility towards them.

Social responsibility is the value that stimulates positive social and moral behaviors of individuals, relationships with others and the realization of the principles of care and justice that allow the individual to strike a balance between empathy with others and care about justice (Wray-Lake \& Syvertsen, 2011: 12). This is what the study of (Wang \& Juslin, 2012) showed in the need to pay attention to the social responsibility and development of the university students because of its impact on their professional future.

\section{Problems of the Study}

Some studies (Pavenkov, Pavenkov \& Rubtcova, 2015; Kim \& Han, 2018) suggest that altruistic behavior is one of the best behaviors acquired in human life and is one of the most important aspects of positive personality development. Although studies have examined the relationship between altruistic behavior and social responsibility, The studies concerned the relationship between them in different samples, such as (Gutierrez, Escarti \& Pascual, 2011) which dealt with the relationship between altruistic behavior and social responsibility in a sample of graduates, and the study of (Jurik, 2014) which examined the relationship between altruistic behavior and social responsibility among the owners of companies, The researcher did not find- in the limits of researcher's acquaintance- a study focused on examining the relationship between altruistic behavior and social responsibility among students of the Faculty of Nursing despite the importance of their role in patient care.

Concerning the relationship between empathy and each of altruistic behavior and social responsibility, (Steele et al., 2008; Gutierrez, Escarti \& Pascual, 2011) noted that there is a relationship between empathy, altruistic behavior, and social responsibility, and although there is a relationship between empathy and each of altruistic behavior and social responsibility but there are no studies- in the limits of researcher's acquaintance - cared about the modified role of the empathy in this relationship, (Fang, chang \& Shu, 2015) showed the modified role of empathy in the relationship between body image and depression, and the study of (Xie, Bagozzi \& Gronhoug, 2019) showed the modified role of 
empathy in the relationship between ethical identity and social responsibility, and the study of (Wright, Wachs \& Harper, 2018) showed the modified role of empathy in the relationship between electronic bullying and anxiety. The study of (Liu et al., 2017) showed the modified role of empathy in the relationship between altruistic behavior and genetics. The study of (Wang et al., 2019) showed the modified role of empathy between positive social behavior and aggressiveness. So, the current study cares about the moderating role of empathy in the relationship between altruistic behaviors the social responsibility among female students of the Faculty of Nursing.

The problem of study can be determined in an attempt to answer the following questions:

1- Is There a relationship between altruistic behavior and Social responsibility in a sample of female students in the Faculty of Nursing?

2- Is There a relationship between empathy, altruistic behavior, and social responsibility among a sample of female students in the Faculty of Nursing?

3- Is Statistical isolation of empathy from the relationship between altruistic behavior and social responsibility weakens the strength of this relationship?

After reviewing the theoretical framework and previous studies, the study hypotheses can be formulated as follows:

1- There is a statistically significant relationship between altruistic behavior and social responsibility in a sample of female students in the Faculty of Nursing.

2- There is a statistically significant relationship between empathy, altruistic behavior, and social responsibility among a sample of female students in the Faculty of Nursing.

3- The statistical isolation of the impact of degrees of empathy on the relationship between altruistic behavior and social responsibility weakens the strength of this relationship. 


\section{Method and Procedures:}

Method: The present study followed the descriptive correlational method.

Participants: The sample consisted of (150) female students. Their mean age was 21,5 years $(\mathrm{SD} \pm 3,4)$.

\section{The Scales of the study:}

\section{Empathy Scale (Prepared by the researcher)}

After doing the first image of the scale, the researcher applied the scale on a pilot study consisted of (100) female students.

\section{Steps to prepare empathy scale}

The Arab and foreign theoretical frameworks and previous studies have been reviewed to define a procedural concept of the empathy among Faculty of Nursing female students, the scale included the following questions: A-What is the meaning of empathy, in your view?.

B-From your point of view, what factors affect an the individual's feeling of empathy for others?

From the responses of the Participants, the researcher was able to formulate a set of Items. The scale was presented in its initial form to some of the Professors specialized in the field of psychology and mental health to provide their opinions on the formulation of items, and the exclusion of inappropriate and repetitive Items.

Although there are several measures in empathy, the researcher did not use these Scales, because some of them were prepared in different cultures, while others were prepared for university students such as (Ali \& Bozorgi, 2016) And some were prepared on kindergarten teachers. Also, some of these Scales contain some items that are not appropriate for the current study sample.

\section{Validity of empathy scale:}

The researcher used Factorial validity through Principle Component Factor analysis, with orthogonal rotation. The factor analysis of the items yielded two high loaded factors labeled Emotional empathy, Cognitive empathy, th+-e eigen values of the two factors (and the percentages of variance accounted for) were 6.44 (17.40\%), 3.25 $(8.78 \%)$. The factor analysis resulted in the exclusion of (7) phrases, Table (1) Presents 30 items loadings on the two factors. 


\section{Table (1)}

Loadings of items on the two factors after rotation

\begin{tabular}{|c|c|c|c|}
\hline Item Number & $\begin{array}{c}\text { Factor } \\
\text { (1) }\end{array}$ & $\begin{array}{c}\text { Item } \\
\text { Number }\end{array}$ & $\begin{array}{c}\text { Factor } \\
\text { (2) }\end{array}$ \\
\hline 1 & 0.74 & 20 & 0.68 \\
\hline 2 & 0.73 & 21 & 0.66 \\
\hline 3 & 0.70 & 22 & 0.57 \\
\hline 4 & 0.69 & 23 & 0.56 \\
\hline 5 & 0.68 & 24 & 0.55 \\
\hline 6 & 0.66 & 25 & 0.55 \\
\hline 7 & 0.64 & 26 & 0.50 \\
\hline 8 & 0.64 & 27 & 0.47 \\
\hline 9 & 0.62 & 28 & 0.47 \\
\hline 10 & 0.61 & 29 & 0.47 \\
\hline 11 & 0.59 & 30 & 0.44 \\
\hline 12 & 0.59 & & \\
\hline 13 & 0.58 & & \\
\hline 14 & 0.57 & & \\
\hline 15 & 0.56 & & \\
\hline 16 & 0.54 & & \\
\hline 17 & 0.51 & & \\
\hline 18 & 0.49 & & \\
\hline 19 & 0.47 & & \\
\hline Eigenvalue & 6.44 & \multicolumn{2}{|c|}{3.25} \\
\hline $\begin{array}{l}\text { Percentages } \\
\text { of Variance }\end{array}$ & $17.40 \%$ & \multicolumn{2}{|c|}{$8.78 \%$} \\
\hline
\end{tabular}

The researcher also used criteria validity and finding the correlation between the Empathy Scale (By the researcher) and Empathy Scale (By mahriban \& Ebsten, Translated and Modified by Al-Asmi, and Shehadeh, 2016) $(r=0.81, \mathrm{p}<.01)$ denoting the scale validity. 


\section{Reliability of empathy Scale:}

Split-half reliability with Spearman-Brown was 0.94 among the pilot sample; Alpha reliability was 0.85 denoting high internal consistency and temporal reliability.

\section{Internal Consistency of empathy Scale:}

The researcher also used internal consistency by finding the correlation between item and dimension, then the correlation between dimension and total score of empathy scale. The coefficients between items and first dimension (Emotional empathy) range between 0.42 and $0.68(\mathrm{P}<0.01)$. The coefficients between items and second dimension (cognitive empathy) range between 0.43 and $0.72(\mathrm{P}<0.01)$. The coefficients between the two dimension (Emotional empathy, and cognitive empathy) and the total score were: $(\mathrm{r}=0.81,0.97, \mathrm{P}<0.01)$.

The scale in its final image contains 30 short statements answered on a 3-point format, anchored by 1 (Disagree) and 3 (Agree). The total score can range from 30 to 90.

\section{Altruistic behavior Scale (Prepared by the researcher)}

Despite the interest of many Arab and foreign studies in studying altruistic behavior at various age levels, and in various areas of life, most studies did not highlight the study of altruistic behavior among students of the Faculty of Nursing, which prompted the researcher to prepare a scale that serves the subject of her study.

\section{Validity of altruistic behavior scale:}

The researcher used Factorial validity through Principle Component Factor analysis, with orthogonal rotation. The factor analysis of the items yielded three high loaded factors labeled Helping behavior, Volunteer behavior and Rescue behavior, the eigen values of the three factors (and the percentages of variance accounted for) were 4.47 $(11.76 \%), 3.44(9.05 \%), 3.21(8.44 \%)$, The factor analysis resulted in the exclusion of (6) phrases, Table (2) Presents 32 items loadings on the three factors. 


\section{Table (2)}

Loadings of items on the three factors after rotation

\begin{tabular}{|c|c|c|c|c|c|}
\hline $\begin{array}{c}\text { Item } \\
\text { Number }\end{array}$ & $\begin{array}{l}\text { Factor } \\
\text { (1) }\end{array}$ & $\begin{array}{c}\text { Item } \\
\text { Number }\end{array}$ & $\begin{array}{c}\text { Factor } \\
(2)\end{array}$ & $\begin{array}{c}\text { Item } \\
\text { Number }\end{array}$ & $\begin{array}{c}\text { Factor } \\
(3)\end{array}$ \\
\hline 1 & 0.78 & 12 & 0.68 & 24 & 0.78 \\
\hline 2 & 0.76 & 13 & 0.62 & 25 & 0.68 \\
\hline 3 & 0.73 & 14 & 0.61 & 26 & 0.65 \\
\hline 4 & 0.70 & 15 & 0.58 & 27 & 0.61 \\
\hline 5 & 0.69 & 16 & 0.54 & 28 & 0.61 \\
\hline 6 & 0.67 & 17 & 0.50 & 29 & 0.56 \\
\hline 7 & 0.58 & 18 & 0.50 & 30 & 0.54 \\
\hline 8 & 0.55 & 19 & 0.48 & 31 & 0.43 \\
\hline 9 & 0.50 & 20 & 0.48 & 32 & 0.43 \\
\hline 10 & 0.49 & 21 & 0.48 & & \\
\hline 11 & 0.46 & 22 & 0.46 & & \\
\hline & & 23 & 0.44 & \multirow{2}{*}{\multicolumn{2}{|c|}{3.21}} \\
\hline Eigenvalue & 4.47 & \multicolumn{2}{|c|}{3.44} & & \\
\hline $\begin{array}{l}\text { Percentages } \\
\text { of Variance }\end{array}$ & $11.76 \%$ & \multicolumn{2}{|c|}{$9.05 \%$} & \multicolumn{2}{|c|}{$8.44 \%$} \\
\hline
\end{tabular}

The researcher also used criteria validity and finding the correlation between altruistic behavior scale (By the researcher) and altruistic behavior scale (by Shoukair, 2017) $(r=0.75, \mathrm{p}<.01)$ denoting the scale validity.

\section{Reliability of altruistic behavior Scale:}

Split-half reliability with Spearman-Brown was 0.95 among the pilot sample; Alpha reliability was 0.90 denoting high internal consistency and temporal reliability.

\section{Internal Consistency of altruistic behavior Scale:}

The researcher also internal consistency by finding the correlation between item and dimension, then the correlation between dimension and total score of altruistic behavior scale.

The coefficients between items and first dimension (Helping behavior) range between 0.27 and $0.62(\mathrm{P}<0.01)$. The coefficients between items and second dimension (Volunteer behavior) range between 0.40 and $0.73(\mathrm{P}<0.01)$. The coefficients between items and third dimension (Rescue behavior) range between 0.40 and $0.77(\mathrm{P}<$ 0.01). The coefficients between the three dimension (Helping behavior, Volunteer behavior and Rescue behavior) and the total score were: ( $\mathrm{r}=$ $0.77,0.82,0.77, \mathrm{P}<0.01)$. 
The scale in its final image contains 32 short statements answered on a 3-point format, anchored by 1 (Disagree) and 3 (Agree). The total score can range from 32 to 96.

\section{Social Responsibility Scale (Prepared by the researcher)}

The researcher prepared a scale of social responsibility to suit the study sample, as most of the scales dealt with different samples, so the researcher sought to prepare this scale in order to achieve the goals of the current study.

\section{Validity of Social Responsibility:}

The researcher used Factorial validity through Principle Component Factor analysis, with orthogonal rotation. The factor analysis of the items yielded three high loaded factors labeled Interesting, participation and Affiliation the eigen values of the three factors (and the percentages of variance accounted for) were 4.29 (8.09\%), 3.96 (7.47\%), 2.95 $(5.56 \%)$, The factor analysis resulted in the exclusion of (13) phrases, Table (3) Presents 40 items loadings on the three factors.

\section{Table (3)}

\section{Loadings of items on the three factors after rotation}

\begin{tabular}{|c|c|c|c|c|c|}
\hline $\begin{array}{c}\text { Item } \\
\text { Number }\end{array}$ & $\begin{array}{c}\text { Factor } \\
\text { (1) }\end{array}$ & $\begin{array}{c}\text { Item } \\
\text { Number }\end{array}$ & $\begin{array}{c}\text { Factor } \\
\text { (2) }\end{array}$ & $\begin{array}{c}\text { Item } \\
\text { Number }\end{array}$ & $\begin{array}{c}\text { Factor } \\
\text { (3) }\end{array}$ \\
\hline $\mathbf{1}$ & 0.75 & 15 & 0.67 & 30 & 0.55 \\
\hline 2 & 0.72 & 16 & 0.59 & 31 & 0.54 \\
\hline 3 & 0.66 & 17 & 0.58 & 32 & 0.53 \\
\hline 4 & 0.65 & 18 & 0.57 & 33 & 0.51 \\
\hline 5 & 0.63 & 19 & 0.56 & 34 & 0.50 \\
\hline 6 & 0.56 & 20 & 0.56 & 35 & 0.49 \\
\hline 7 & 0.53 & 21 & 0.56 & 36 & 0.49 \\
\hline 8 & 0.51 & 22 & 0.54 & 37 & 0.48 \\
\hline 9 & 0.47 & 23 & 0.53 & 38 & 0.45 \\
\hline 10 & 0.44 & 24 & 0.49 & 39 & 0.44 \\
\hline 11 & 0.42 & 25 & 0.49 & 40 & 0.41 \\
\hline 12 & 0.42 & 26 & 0.48 & & \\
\hline 13 & 0.41 & 27 & 0.46 & & \\
\hline 14 & 0.41 & 28 & 0.45 & & \\
\hline & & 29 & 0.43 & & \\
\hline Eigenvalue & 4.29 & \multicolumn{2}{|c|}{3.96} & \multicolumn{2}{|c|}{2.95} \\
\hline $\begin{array}{l}\text { Percentages } \\
\text { of Variance }\end{array}$ & $8.09 \%$ & \multicolumn{2}{|c|}{$7.47 \%$} & \multicolumn{2}{|c|}{$5.56 \%$} \\
\hline
\end{tabular}

The researcher also used criteria validity and finding the correlation between Social Responsibility scale (By the researcher) and Social 
Responsibility scale (by Othman, 2010) $(\mathrm{r}=0.67, \mathrm{p}<.01)$ denoting the scale validity.

\section{Reliability of Social Responsibility Scale:}

Split-half reliability with Spearman-Brown was 0.92 among the pilot sample; Alpha reliability was 0.92 denoting high internal consistency and temporal reliability.

\section{Internal Consistency of Social Responsibility Scale:}

The researcher also used internal consistency by finding the correlation between item and dimension, then the correlation between dimension and total score of Social Responsibility scale.

The coefficients between items and first dimension (Interesting) range between 0.50 and $0.72(\mathrm{P}<0.01)$. The coefficients between items and second dimension (participation) range between 0.34 and $0.69(\mathrm{P}<$ 0.01). The coefficients between items and third dimension (Affiliation) range between 0.26 and $0.56(\mathrm{P}<0.01)$. The coefficients between the three dimension (Interesting, participation and Affiliation) and the total score were: $(r=0.88,0.92,0.93, \mathrm{P}<0.01)$.

The scale in its final image contains 40 short statements answered on a 3-point format, anchored by 1 (Disagree) and 3 (Agree). The total score can range from 40 to 120 .

\section{Procedures}

The scales were administered anonymously to (150) female students in the academic year 2018/2019.

SPSS version 20 was used for the statistical analysis of the data Descriptive statistics, Person correlation, and Partial correlation were used.

\section{Results}

First Hypothesis: The first hypothesis states that "there is a statistically significant relationship between altruistic behavior and social responsibility among Faculty of Nursing female students ".

To verify the validity of this hypothesis, the researcher calculated the value of the Pearson correlation coefficient. Table (4) shows the correlation coefficient " $r$ " between the scores of the Participants on altruistic behavior and social responsibility. 
Values of correlation coefficient " $r$ " between the scores of the Participants on altruistic behavior and social responsibility

\begin{tabular}{|c|c|c|c|c|}
\hline $\begin{array}{c}\text { Altruistic } \\
\text { behavior } \\
\text { social } \\
\text { responsibility }\end{array}$ & $\begin{array}{c}\text { Volunteer } \\
\text { behavior }\end{array}$ & $\begin{array}{c}\text { Helping } \\
\text { behavior }\end{array}$ & $\begin{array}{c}\text { Altruistic } \\
\text { behavior } \\
\text { "Total } \\
\text { Score" }\end{array}$ \\
\hline Interesting & $0.60 * *$ & $0.62 * *$ & $0.49 * *$ & $0.65 * *$ \\
\hline Participation & $0.69 * *$ & $0.59 * *$ & $0.56 * *$ & $0.79 * *$ \\
\hline $\begin{array}{c}\text { Affiliation } \\
\text { Social } \\
\text { responsibility } \\
\text { "Total Score" }\end{array}$ & $0.57 * *$ & $0.64 * *$ & $0.61 * *$ & $0.72 * *$ \\
\hline
\end{tabular}

It is clear from Table (4) that there is a positive statistically significant relationship between altruistic behavior and social responsibility at the level of significance of 0.01 , and this result indicates the validity of the hypothesis.

Second Hypothesis: The second hypothesis states that "there is a statistically significant relationship between empathy, altruistic behavior, and social responsibility among Faculty of Nursing female students."

To investigate the validity of this hypothesis, the researcher calculated the value of the Pearson correlation coefficient. Table (5) shows the values of correlation coefficient " $r$ " between the Participants scores on empathy, altruistic behavior and social responsibility.

Table (5)

Values of correlation coefficient " $r$ " between the Participants scores on empathy, altruistic behavior and social responsibility

\begin{tabular}{|c|c|c|}
\hline Variables & $\begin{array}{c}\text { Altruistic } \\
\text { behavior }\end{array}$ & $\begin{array}{c}\text { Social } \\
\text { responsibility }\end{array}$ \\
\hline Emotional Empathy & $0.89^{* *}$ & $0.81^{* *}$ \\
\hline Cognitive Empathy & $0.85^{* *}$ & $0.80^{* *}$ \\
\hline Empathy "total score" & $0.90^{* *}$ & $0.83^{* *}$ \\
\hline
\end{tabular}

Table (5) shows a statistically significant positive correlation between empathy and altruistic behavior and social responsibility at the 
level of significance of 0.01 , and this result indicates that the validity of the hypothesis is valid.

Third hypothesis: states that "the statistical isolation of the impact of empathy on the relationship between altruistic behavior and social responsibility weakens the strength of this relationship".

To verify the validity of this hypothesis, the researcher calculated the value of the partial correlation coefficients by eliminating the effect of empathy on the relationship between altruistic behavior and social responsibility. Table (6) shows partial correlation coefficient values by eliminating the impact of empathy on the relationship between altruistic behavior and social responsibility.

\section{Table (6)}

Partial correlation coefficient values by eliminating the impact of empathy on the relationship between altruistic behavior and social responsibility

\begin{tabular}{|c|c|c|}
\hline Variables & $\begin{array}{c}\text { Value of simple } \\
\text { correlation } \\
\text { coefficient }\end{array}$ & $\begin{array}{c}\text { Value of partial } \\
\text { correlation } \\
\text { coefficient }\end{array}$ \\
\hline $\begin{array}{c}\text { Altruistic behavior and social } \\
\text { responsibility }\end{array}$ & $0.81 * *$ & $0.49 * *$ \\
\hline
\end{tabular}

It is clear from Table (6) that when the statistical isolation of the Empathy effect on the relationship between altruistic behavior and social responsibility was reduced, the correlation value decreased from $0.81 * *$ to $0.49 * *$, and there was a change in the correlation coefficient, indicating that the variable of empathy has an impact in the direction and strength of the relationship between altruism and social responsibility and this result indicates the validity of the hypothesis.

\section{Discussion:}

The results of the first hypothesis showed that there is a positive statistically significant relationship between altruistic behavior and social responsibility, The results of this hypothesis are consistent with the results of (Steele et al., 2008; Rim, Yang \& Lee, 2016). The results of their studies have shown that there is a positive relationship between altruistic behavior and social responsibility. Altruistic behavior improves the level of social responsibility of the individual, and this is consistent 
with what is shown in the study of (Ali \& Bozorgi, 2016) that the individual's assimilation of social responsibility enhances his tendency to altruism and his lack of indifference toward others. A person who feels socially responsible towards others tends to help them and help them and be motivated to altruism towards others.

In this context, the study of (Jurik, 2014) indicates that there is a positive correlation between altruistic behavior and social responsibility, that is, students with high altruism have a high level of social responsibility, as showed by ( Aziz \& Abid, 2018) that altruistic behavior and social responsibility are a part of human nature. Social responsibility has a great influence on the personality of the individual.

The study of (Lee et al., 2017) showed that there is a relationship between altruistic behavior and social responsibility, which means that the sense of social responsibility reflects the role of the individual in the society in which he lives and his doing of altruistic behaviors toward others. People who have social responsibility were more altruistic and more voluntary and to promote benevolent behavior. Social responsibility is one of the fundamental principles of altruistic behavior, that is, the individual considers himself responsible to others, thus enhancing the responsiveness of social responsibility.

In this regard (Tam \& Yeung, 2012) noted that society as a whole must participate in altruism and therefore reflect a sense of social responsibility. The individual's willingness to help others is largely related to their interests as a priority of social responsibility. Therefore, social responsibility is the specific determinant of altruistic behavior. Personal characteristics have an influence on altruistic behavior because responsible individuals exhibit cognitive and sentimental responses that include aid and volunteerism, as well as the relationship between altruistic behavior and social responsibility through volunteering to serve others.

The results of the second hypothesis showed a statistically significant positive correlation between empathy and altruistic behavior and social responsibility, The result of this hypothesis is consistent with what (Bierhoff \& Rohmann,2004; Steele et al., 2008) have shown that there is a relationship between empathy, altruistic behavior and social responsibility, and that individuals with high levels of empathy have a high level of altruistic behavior and social responsibility, and this is 
shown in the study of (Previte et al., 2019) that empathy has a role in altruistic behavior. (Batson, 2011: 11), showed in the writing of "human altruism," that sympathetic anxiety is an incentive for altruism, because empathy is for the individual to feel what others feel and to feel the suffering of other individuals to be able to help them. Individuals who have experienced misery $\mathrm{n}$ their lives are particularly enthusiastic about helping others, and Staub has formulated the term "altruism born from suffering". People who have been grossly neglected or subjected to torture and persecution devote themselves to helping others rather than become anti-social (Staub \& Vollardt, 2008: 271).

Perhaps this is what (Jie et al., 2018; Mayer et al., 2018) suggests that an individual who has the ability to help has compassion for others, a sense of responsibility, and knowledge of existing social norms. Individuals feel happy and satisfied when achieving goals that are consistent with their interests and values, especially behaviors that are automatically chosen rather than forced.

Altruistic behavior is an automatic and intentional behavior accompanied by a kind of social responsibility and empathy towards others. The person introduces the other to himself, both in ordinary and emergency situations, for the benefit of the other. It is also in providing help and assistance to the other, sacrificing and giving up his interests for the benefit of the other. This is illustrated by the study by (Gutierrez, Esarti \& Pascual, 2011) that empathy is accompanied by altruistic behavior and a sense of social responsibility.

The results of the Third hypothesis showed that when the statistical isolation of the Empathy effect on the relationship between altruistic behavior and social responsibility was reduced, the correlation, On the modified role of empathy, the results of partial correlation coefficients revealed the importance of empathy in modifying the relationship between altruism and social responsibility. This can be explained in the light of the results of the study (Rieffe, Ketelear \& Wiefferink, 2010; Gutierrez, Esarti \& Pascual, 2011). The individuals who have high scores of tendency to empathy is marked by high levels of social responsibility according to altruistic behavior, and this study (Rabelo \& Pilati, 2017) suggests that empathy has a mediating role between social responsibility and the positive inclination to help others. Individuals who have a greater tendency to empathize with others were more likely to 
help others and provide assistance to them based on their sense of social responsibility.

The study of (Narimani et al., 2013) indicates that empathy has an influence on the relationship between altruistic behavior and social responsibility, as (Patil et al., 2018) has shown that altruism is motivated by empathy. Empathy, as one of positive emotions, has a role in creating altruism in the individual and society and this is related to social responsibility.

In this context, the study (Kim \& Han, 2018; Cartabuke et al., 2017) suggests that empathy has an important role to play in an individual's emotional health. The ability to recognize what others feel and share in their emotional state helps to interact in social situations. The highest levels of empathy predict positive outcomes such as control of emotions and altruism. Those who are willing to take responsibility for their actions and accept the consequences of their behavior are more sympathetic and more positive in social attitudes.

\section{Recommendations and Suggested researches:}

\section{A) Study recommendations:}

In light of the results of the study, the researcher suggests some recommendations that can be used, and can be summarized as follows:

1- Providing a suitable family environment based on empathy, cooperation and participation.

2- The interest of educational institutions in the programs of developing altruistic behavior among university students, which helps them achieve success in their scientific lives.

3- The study recommends that specialists in the field of psychological counseling hold counseling programs and seminars aimed at promoting altruistic behavior, empathy and participation in social activities.

\section{B) Suggested researches:}

It can be derived from the theoretical basis upon which the current research was based and the results of a number of proposed researches that can achieve more depth in analysis and study as follows:

1- Empathy and its relationship to a big five personality in medical students. 
2- 2-The effectiveness of a behavioral cognitive program to develop altruistic behavior among a sample of university students and its impact on social responsibility.

3- Predicting empathy through social support and life skills.

4- A systematic review of the associations between empathy measures and patient outcomes in cancer care.

\section{References:}

Al-Asmi, R., \& Shehadeh, A. M. (2016). Adherence to peers and its relation to emotional empathy in a sample of master students in the Faculty of Education. University of Damascus, Journal of Psychological and Educational Sciences. 3 (1), 170195.(Arabic Text).

Ali, R. M., \& Bozorgi, Z. D. (2016). The Relationship of Altruistic Behavior, Empathetic Sense, and Social Responsibility with Happiness among University Students. Practice in Clinical Psychology, 4( 1),51-56.

Aziz, M., \& Abid, M. (2018). Social responsibility: As a predictor of altruistic personality among adults. Psychology and Behavioral Science- international Journal, 8(5), 1-4.

Batson, C. D. (2011). Altruism in humans. New York: Oxford University Press.

Bierhoff, W. H., \& Rohmanne, E.(2004). Altruistic personality in the context of the Empathy-Altruism Hypothesis. European Journal of Personality, 18, 351-365.

Cartabuke, M., Westerman, W. J., Bergman, Z. J., Whitaker, G. B., Westerman, J., \& Beekun, I. R. (2017). Empathy as an Antecedent of social Justice Attitudes and perceptions. Journal of Business Ethics, 40,290-302.

Fang, Y. S., Chang, T. H., \& Shu, C. B.(2015). The moderating effect of perceived partner empathy on body image and depression among breast cancer. Journal of the psychological, Social and Behavioral Dimensions of cancer, 24(12),1815-1822.

Gutierrez, S. M., Escarti, C., \& Pascual, B. C. (2011). Relationships among empathy, prosaically behavior, aggressiveness, self- 
efficacy and pupils personal and social responsibility. Piscothema, 23( 1), 13-19.

Jiang, H.,Chen, G., \& Wang, T. (2017). Relationship between belief in a just world and Internet altruistic behavior in a sample of Chinese undergraduates: Multiple mediating roles of gratitude and self-esteem. Personality and Individual Differences, 104,493-498.

Jie, H. u.,Yue, L., Yin, Y., Blue, R. P.,Hongbo, Y., \& Zhou,X. (2018). How do self-interest and other-need interact in the brain to determine altruistic behavior?.NeuroImage,157,598-611.

Jurik, C. N. (2014). social responsibility and Altruism in small and medium-sized innovative Business. The Journal of Sociology \& social Welfare,41(4), 113-141.

Kim, H., \& Han, S. (2018). Does Personal distress enhance empathic interaction or block it?. Personality and individual Differences, 124,77-83.

Lee, Y. S., Jung, S., Oh, S., \& Park, H. S. (2017). Others Participation rate Influences an individual's Charitable Behavior: Others similarity as moderator. Social Behavior\& Personality: an international journal,45(10),1607-1618.

Levett-Jones, T., Cant, R., \& Lapkin, S.(2019). A Systematic review of effectiveness of empathy education for undergraduate nursing students. Nurse Education today,75,80-94.

Liu, Y., Gong, P., Li, h., \& Zhou, X. (2017). A field study of the association between CD 38 gene and altruistic behavior: Emphatic response as a mediator. Psych neuroendocrinology, $85,165-171$.

Mayer, S., Jusyte, A., Klimecki, L., \& Schonenberg, M. (2018). Empathy and altruistic behavior of antisocial violent offenders with psychopathic traits. Psychiatry Research, 269, 625 -632.

Narimani, M., Sadeghieh, A. S., Esmaili, N. A., \&Solimani, E. (2013). The Comparison of altruistic behavior empathetic sense, and social responsibility among voluntary and non-voluntary blood donors. Scientific Journal of Iranian Blood Transfusion Organization Iran, 10(2), 190-197. 
Othman, S.A. (2010). Social Responsibility Scale. Cairo: The AngloEgyptian Library. (Arabic Text).

Patil, I., Zanon, M., Novemdre, G., Zangrando, N., Chittaro, C., \& Silani, G. (2018). Neuroanatomical basis of Concern -based altruism in virtual environment. Journal Neuropsychologia, 31(116),34-43.

Pavenkov, O., Pavenkov, V., \& Rubtcova, M. (2015). The altruistic behavior: Characteristic of future teachers of Inclusive education is Russia. Procedia-Social and behavioral Sciences, $187,10-15$.

Previte, J., Russell, B. R., Mulcahy, R., \& Hartel, C. (2019). The role ofemotional value for reading and giving ewomin in altruistic scrvices. Journal of Business Research, 99,157-166.

Rabelo, A., \& Pilati, R. (2017). Empathy is a stable predictor of compassionate emotions independent of an attribution of responsibility manipulation

Universitas Psychologica, 16(1),40-49.

Rieffe, C., Ketelear, L., \& Wiefferink, C. H. (2010). Assessing empathy in young children: construction and validation of an empathy questionnaire (emque). Personality and Individual Difference, 49(5), 362-367.

Rim, H., Yang, U. S., \& Lee, J. (2016). Strategic partnerships with nonprofits in corporate social responsibility (CSR): The mediating role of perceived altruism and organizational identification. Journal of Business Research, 69(9),3213-3219.

Roberts, W., Strayer, J., \& Denham, S. (2014). Empathy, anger, guilt: Emotions and prosocial behavior. Canadian Journal of Behavioral Science,46(4),465-474.

Shoukair, Z. (2017). Alturism Diagnosis Battery- "Fields and typesPositve and negative personal and external motives in the Arab environment (Egypt and Saudi Arabia). Cairo: The AngloEgyptian Library. (Arabic Text).

Staub, E., \& Volhardt, J. (2008). Altruism born of suffering: The roots of Caring and helping after victimization and other trauma. American Journal of Ortho Psychiatry,78(3),267-280. 
Steele, R. W., Schreiber, B. G., Guiltinan, A., Nass, C., Glynn, S. A., Wright, D. J., Kessler, D., Schlumpf, K. S., Smith, J. W., \&Garratty, G. (2008). The role of altruistic behavior empathic Concern and social responsibility Motivation in blood donation behavior. The Journal of Transfusion, 48,43-54.

Tam, T. S., \& Yeung, S. (2012). Altruism, Social responsibility and Government support for Social welfare. Asia pacific Journal of Social work and development, 9(2), 79-95.

Wang, L., \& Juslin, H. (2012). Values and corporate social responsibility perceptions of Chinese university students. Journal of Academic Ethics, 10, 57 - 82.

Wang, M., Wang, J., Deng, X., \& Chen, W.(2019). Why empathic children areliked by peers? The mediating roles of prosaical and aggressive behaviors Personality and individual Differences, $144,19-23$.

Wary-Lake, L., \& Syvertsen, A. K. (2011). The development roots of social responsibility in childhood and Adolescent. New Directions for Child \& Adolescent Development, 134, 11-25.

Wright, F. M., Wachs, S., \& Harper, B. D. (2018). The moderation of empathy in the longitudinal association between witnessing cyber bullying, depression, and anxiety. Journal of psychosocial Research on cyberspace, 12 (4), 1-6.

Xie, C.,Bagzzi, P. R., \& Gronhaug, K. (2019). The impact of corporate social responsibility on consumer brand advocacy: The role of moral emptions, attitudes, and individual differences. Journal of Business Research,95,514 -530.

Zheng, X., Wang, Y., \& Xu, L. (2016). Internet altruistic behavior and subjective well-being: self-efficacy as a mediator. Social Behavior and Personality: An international journal, 44(9),1575-1584. 


\section{التعاطف كمتفير معدل للعلاقة بين السلوك الإيثارى والمسئولية الاجتماعية للدى طاالبات كلية التمريض * مريم أحمد الشنهاوك}

هدفت هذه الدراسة إلى التعرف على العلاقة بين السلوك الإيثارى والمسئولية الاجتماعية، كما هدفت أيضًا إلى التعرف على العلاقة بين التعاطف وكل من السلوك الإيثارى والمسئولية الاجتماعية، كما هدفت إلى التعرف على الدور المعدل للتعاطف في العلاقة بين السلوك الإيثاري والمسئولية الاجتماعية. وتتكون العينة من ( . (1) طالبة، بمتوسط عمرى قدره (Y,0) عامًا، وانحراف معيارى قدره (ع,Y)، تم تطبيق مقياس التعاطف (إعداد الباحثة)، ومقياس السلوك الإيثارى (إعداد الباحثة)، ومقياس المسئولية الاجتماعية (إعداد الباحثة). أوضحت نتائج الدراسة أنه توجد علاقة دالة إحصيائيًا موجبة بين السلوك الإيثارى والمسئولية الاجتماعية كما توجد علاقة دالة إحصائيًا بين التعاطف وكل من السلوك الإيثارى والمسئولية الاجتماعية، كما أوضحت نتائج الدراسة أيضًا الدور المعدل للتعاطف في العلاقة بين السلوك الإيثارى والمسئولية الاجتماعية.

الكلمات المفتاحية: التعاطف- السلوك الإيثارى- المسئولية الاجتماعية. $* * * *$ 


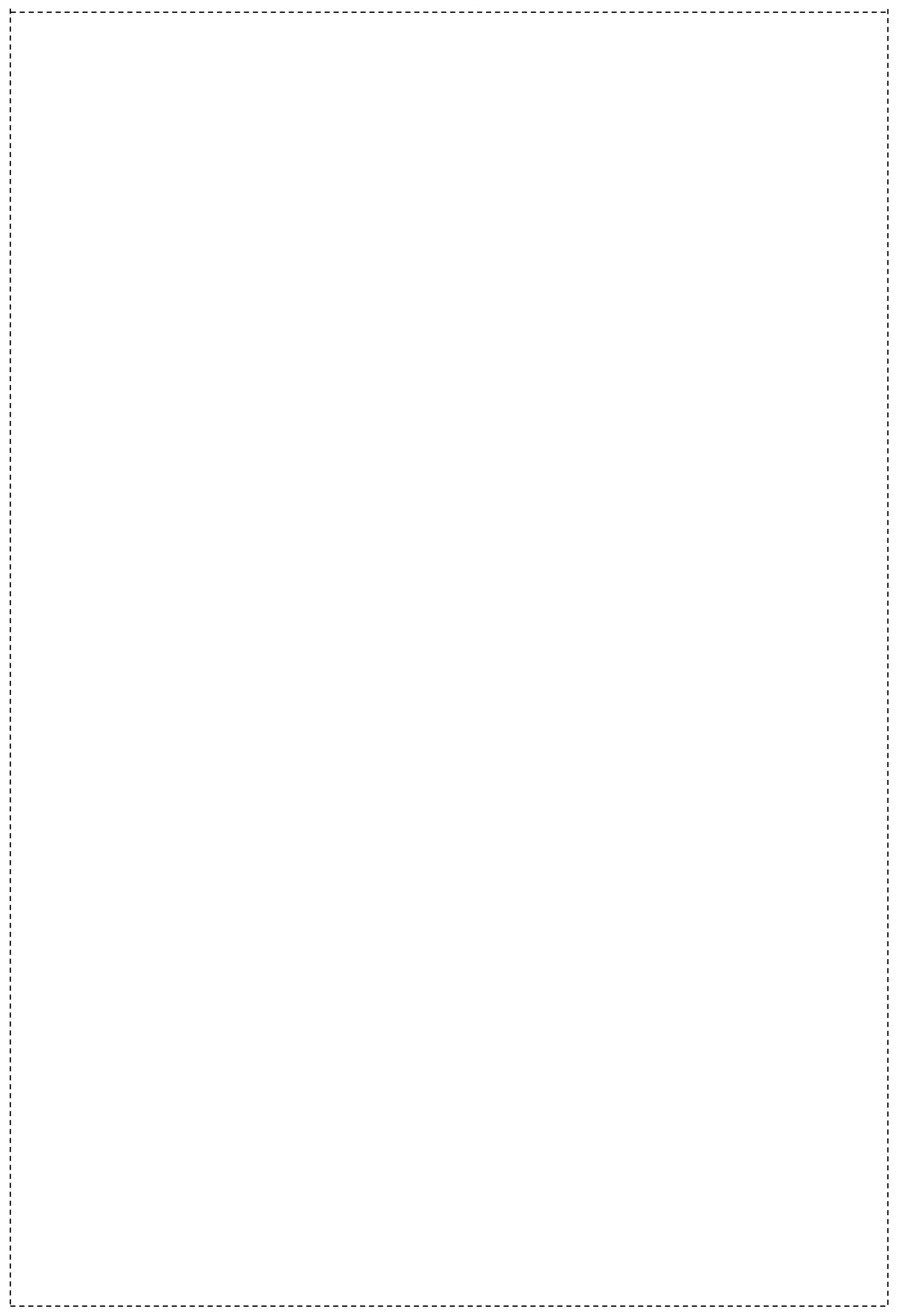

